\title{
Effect of the agitation on the adsorption and hydrolytic efficiency of cutinases on polyethylene terephthalate fibres
}

\author{
Alexandre O’Neill ${ }^{\mathrm{a}}$, Rita Araújo ${ }^{\mathrm{a}, \mathrm{b}}$, Margarida Casal ${ }^{\mathrm{b}}$, \\ Georg Guebitz ${ }^{\mathrm{c}}$, Artur Cavaco-Paulo ${ }^{\mathrm{a}, *}$

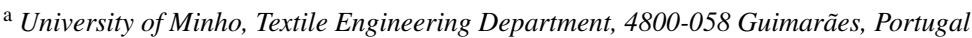 \\ ${ }^{\mathrm{b}}$ University of Minho, Biology Department, 4710-057 Braga, Portugal \\ ${ }^{\mathrm{c}}$ Graz University of Technology, Department of Environmental Biotechnology, 8010 Graz, Austria
}

Received 4 January 2007; received in revised form 22 February 2007; accepted 23 February 2007

\begin{abstract}
The effect of agitation on adsorption, desorption and hydrolytic efficiency of a native and a genetically modified cutinase (L182A) on polyethylene terephthalate fibres is reported in this paper. The effect of mechanical agitation was studied using a shaker bath with orbital agitation and a Rotawash machine with vertical agitation with and without extra steel discs inside the reaction pots. The results obtained indicate that mechanical agitation combined with enzymatic action enhances the adsorption and activity of cutinases towards PET (polyethylene terephthalate) fibres. L182A showed higher adsorption than the native enzyme for all the levels of mechanical agitation. Lower units of L182A lead to similar yields of terephthalic acid formed in all levels of mechanical agitation. The highest increase of hydroxyl surface groups was found for the genetically modified L182A at the lowest level of mechanical agitation with a shaker bath. These results indicate that enzymatic functionalization of PET is favoured with a process with lower levels of mechanical agitation.
\end{abstract}

(C) 2007 Elsevier Inc. All rights reserved.

Keywords: Cutinase; Polyester; Adsorption; Mechanical; Agitation

\section{Introduction}

Advances in biotechnology enabled the design of enzymes with improved catalytic activities towards the substrates of interest and better stabilities than those previously available [1]. The use of genetic engineering stands as a powerful tool that has been used to modify an enzyme to improve its action on polyester fibres [1]. It is known that cutinases are able to catalyse the hydrolysis of ester bonds in polyester, resulting in the generation of hydroxyl and carboxyl groups at the surface and in the formation of terephthalic acid and ethylene glycol as reaction products [2,3]. The cutinase from Fusarium solani pisi is an extracellular enzyme that is naturally designed to catalyse the hydrolysis of cutin, the structural polyester from the cuticle of plants. This enzyme was modified [1], by site directed mutagenesis around the active centre, in order to fit a larger polymer substrate and therefore improve its activity towards a non-natural

\footnotetext{
* Corresponding author. Tel.: +351 253 510271; fax: +351 253510293 .

E-mail address: artur@det.uminho.pt (A. Cavaco-Paulo).
}

substrate such as polyester (PET) fibre. The change of specific amino acid residues was performed based on the native enzyme structure. The modified cutinase L182A has been shown in a previous work to have a higher affinity and to be more effective for polyester hydrolysis than the native one [1].

The process of enzyme adsorption is of key importance concerning fundamental knowledge of enzymatic hydrolysis of water insoluble fibre substrates [1,4-6]. Enzyme adsorption and desorption on polyester is a pre-requisite for the hydrolysis process to occur [7,8]. The adsorption of proteins starts with the formation of various contacts between the adsorbing protein molecule and the sorbent surface $[9,10]$. Protein adsorption is very complex and involves different steps, that have been subject of earlier studies in order to understand this process [11-13]. The hydrophobic amino acids exposed on the surface of the enzyme will lead to binding to the hydrophobic surface of the PET fibre. The important substrate characteristics that influence the enzymatic hydrolysis are: accessibility, degree of crystallinity and degree of polymerization [6].

A balance between enzyme activity and mechanical agitation is required to achieve the desired effect on the textile substrates. 
For cotton fibres, it was observed that high mechanical agitation lead to an increased accessible surface area. Consequently higher levels of enzyme adsorption were measured [14]. The mechanical action on these fibres is expected to protruding fibres and therefore more sites in the fibre for enzymatic attack. In short treatment times, the enzyme attacks what is more exposed, i.e., the pills or raised microfibrils at the fabric surface $[15,16]$.

In this work we studied the influence of the level of mechanical agitation on the adsorption and activity of cutinases on PET fabrics. Industrially suitable conditions such as short processing times were reproduced at both low and high level of mechanical agitation during the enzymatic process. The low level was reproduced with orbital agitation in a shaker bath and the high level with vertical agitation in a laboratory washing machine with and without metal disks added.

\section{Experimental}

\subsection{Materials}

The fabric used was $100 \%$ polyester, $107 \mathrm{~g} \mathrm{~m}^{-2}, 18$ yarns $\mathrm{cm}^{-1}, 29$ Tex (warp and weft) obtained from Rhodia. Activity of cutinases was assayed towards $p$-nitrophenyl butyrate ( $p$-NPB) as described in literature [17]. The enzymes used in this work were cutinases from $F$. solani pisi (native cutinase with a specific activity of $221.0 \mathrm{U}$ ( $\mu \mathrm{mol}$ of $p$-nitrophenol $\mathrm{min}^{-1}$ ) $\mathrm{mg}^{-1}$ and a genetically modified cutinase L182A with a specific activity of $125.0 \mathrm{U}$ ( $\mu \mathrm{mol}$ of $p$-nitrophenol $\left.\mathrm{min}^{-1}\right) \mathrm{mg}^{-1}$ produced and purified as previously described [1]. The dye used for staining was C.I. Reactive Black 5 (RB5) from Ciba, Switzerland. All other chemicals used were laboratory grade reagents.

\subsection{Enzymatic treatment}

The polyester fabric was washed with $2 \%$ (v/v) of Lutensol AT25 at $50^{\circ} \mathrm{C}$ during $60 \mathrm{~min}$, with distilled water for $60 \mathrm{~min}$ at $50^{\circ} \mathrm{C}$ and dried at oven at $40^{\circ} \mathrm{C}$ for $24 \mathrm{~h}$. The enzymatic treatments were performed in sealed, stainless steel dye pots of $400 \mathrm{~cm}^{3}$ in a Rotawash machine (laboratory scale dyeing machine) with and without stainless steel discs (10 discs were used in each pot, each disc with an average weight of $19 \mathrm{~g}, 32 \mathrm{~mm} \times 3 \mathrm{~mm}$ ) with vertical agitation of $40 \mathrm{rpm}$. For comparing different agitation modes, samples were also incubated in $250 \mathrm{~mL}$ glass flaks in a shaker bath with orbital agitation of $80 \mathrm{rpm}$. The enzyme concentration used was $100 \mathrm{mg}_{\text {prot }} \mathrm{L}^{-1}$ of both purified enzymes corresponding to esterase activity of $22.1 \mathrm{U}\left(\mu \mathrm{mol}\right.$ of $p$-nitrophenol $\left.\mathrm{min}^{-1}\right) \mathrm{L}^{-1}$ of native and $12.5 \mathrm{U}$ ( $\mu$ mol of $p$-nitrophenol $\left.\mathrm{min}^{-1}\right) \mathrm{L}^{-1}$ of L182A. The enzymatic treatments were performed at $35^{\circ} \mathrm{C}$ using phosphate $\left(\mathrm{KH}_{2} \mathrm{PO}_{4} 0.1 \mathrm{M}, \mathrm{NaOH} 0.1 \mathrm{M}\right)$ buffer $0.1 \mathrm{M} \mathrm{pH}$ 8.5. All samples were incubated for $5 \mathrm{~h}$. For each incubation period $(1,2,3,4$ and $5 \mathrm{~h})$ a fabric sample and an enzymatic solution sample were taken for further analysis. Five PET fabric samples, each with $0.2 \mathrm{~g}$, were incubated with enzyme in $150 \mathrm{~mL}$ of phosphate buffer. Control samples were incubated in the same buffer solution but without enzyme and samples removed after each incubation period. After enzymatic treatment, all samples were washed first with tap water, then with a $2 \mathrm{~g} \mathrm{~L}^{-1}$ sodium carbonate solution for $60 \mathrm{~min}$ at $50^{\circ} \mathrm{C}$ (to remove the remaining proteins) and finally with distilled water at $50^{\circ} \mathrm{C}$ for $1 \mathrm{~h}$.

\subsection{Staining with reactive dye}

The staining was performed at $60^{\circ} \mathrm{C}$, below the glass transition temperature $\left(T_{\mathrm{g}}\right)$ of PET fibre, which is approximately $69^{\circ} \mathrm{C}$. Polyester fabric samples after enzymatic treatment were stained all together in the same sealed, stainless steel dye pot of $120 \mathrm{~mL}$ capacity in an Ahiba machine (laboratory scale dyeing machine). The dyeing was performed with RB5 (10\%) owf, bath ratio of 100:2 ( $100 \mathrm{~mL}$ of liquor for $2 \mathrm{~g}$ of fabric), at $\mathrm{pH} 11.0$ using $20 \mathrm{~g} \mathrm{~L}^{-1}$ sodium carbonate and $60 \mathrm{~g} \mathrm{~L}^{-1}$ sodium sulphate at $60^{\circ} \mathrm{C}$ during $90 \mathrm{~min}$ with $30 \mathrm{rpm}$ of agitation. After the dyeing process, samples were all washed in a flask with stirring with water at $50^{\circ} \mathrm{C}$ for $1 \mathrm{~h}$ and then dried in an oven at $40^{\circ} \mathrm{C}$ for $24 \mathrm{~h}$.

\subsection{Terephthalic acid (TPA) determination by fluorescence}

We measured the TPA in the enzymatic treatment solution for the different incubation periods in order to study the enzymatic hydrolysis efficiency, since TPA is one of the hydrolysis reaction products. Fluorescence scans were performed with a luminescence spectrometer between 300 and $600 \mathrm{~nm}$ wavelengths after reaction of terephthalic acid solution with hydrogen peroxide $30 \%$ at boiling temperature and using an excitation wavelength of $315 \mathrm{~nm}$. The presence of hydroxy-terephthalic acid (HTA) [18] is detected by analyzing the wavelength of $425 \mathrm{~nm}$. If the concentration of TPA increases, a higher intensity at this wavelength will be observed due to the presence of more HTA ions. One millilitre of solution was added to $2 \mathrm{~mL}$ of hydrogen peroxide and heated at $90^{\circ} \mathrm{C}$ for $30 \mathrm{~min}$. After cooling down to room temperature, samples were measured by fluorescence and the intensity of the peak at $425 \mathrm{~nm}$ was used for the determination of TPA concentration [18].

The calibration curve was determined using standard solutions with different concentrations of TPA $(0.006,0.03,0.06$ and $0.12 \mathrm{mM})$ dissolved in a $0.05 \mathrm{M}$ $\mathrm{NaOH}$ solution. The calibration curve attained shows a linear fit between 0.006 and $0.12 \mathrm{mM}$ TPA with a standard deviation below $4 \%$ and $R^{2}=0.995$. All measurements were performed using duplicate samples and results represent the mean. Values had a standard deviation below $10 \%$.

\subsection{Colour measurements}

The $K / S$ increase after the enzymatic treatments and after staining with a reactive dye (RB5) was measured in order to detect differences of hydroxyl groups formed at the surface [1]. The colorimetric data $(K / S)$ of the dyed samples with Reactive Black 5 was collected using a spectrophotometer Spectraflash 600 plus interfaced to a PC using an illuminant $\mathrm{D}_{65}$ at the wavelength of maximum absorption $(600 \mathrm{~nm})$ as an average of five readings. The control samples were incubated in phosphate buffer solution.

\subsection{Protein adsorption and desorption}

The remaining protein in the enzymatic treatment solution for different incubation periods was measured to study the adsorption and desorption phenomena [1]. For this adsorption/desorption studies the protein in solution was determined by the Bradford method using bovine serum albumin (BSA) as standard [19]. Different time samples of enzymatic treatment solution were measured $(0,1$, $2,3,4$ and $5 \mathrm{~h}$ ). After $5 \mathrm{~h}$ of incubation, the enzymatic treatment solution was diluted (1:2) with the same previously specified phosphate buffer and the mixture was subsequent incubated for another $60 \mathrm{~min}$, with the same agitation and temperature conditions, to verify the desorption phenomena. Values had a standard deviation below $9 \%$. The percentage of adsorption was calculated by the following expressions as described in literature [5]:

$\%$ adsorption $=\frac{A-B}{A} \times 100$
$\%$ desorption $=\frac{D-C}{A} \times 100$

where $A$ is the initial protein concentration (at $0 \mathrm{~h}$ ), $B$ the protein concentration at time $t(1,2,3,4$ and $5 \mathrm{~h}), C$ the dilution (dilution 1:2 with buffer solution) and $D$ is the final protein concentration (after the dilution and 60 more minutes of incubation).

\section{Results and discussion}

The formation of terephthalic acid (TPA) and the protein adsorption for the two studied cutinases, with a low agitation level (shaker bath, 2A) and strong agitation level (Rotawash, 2B), is shown in Fig. 1. In Table 1 the values of percentage of protein adsorbed for the different incubation periods are shown for both modes of mechanical agitation.

In all cases, no desorption was detected after the dilution 1:2 and $1 \mathrm{~h}$ of incubation at $35^{\circ} \mathrm{C}$. Therefore, this data is not shown. 

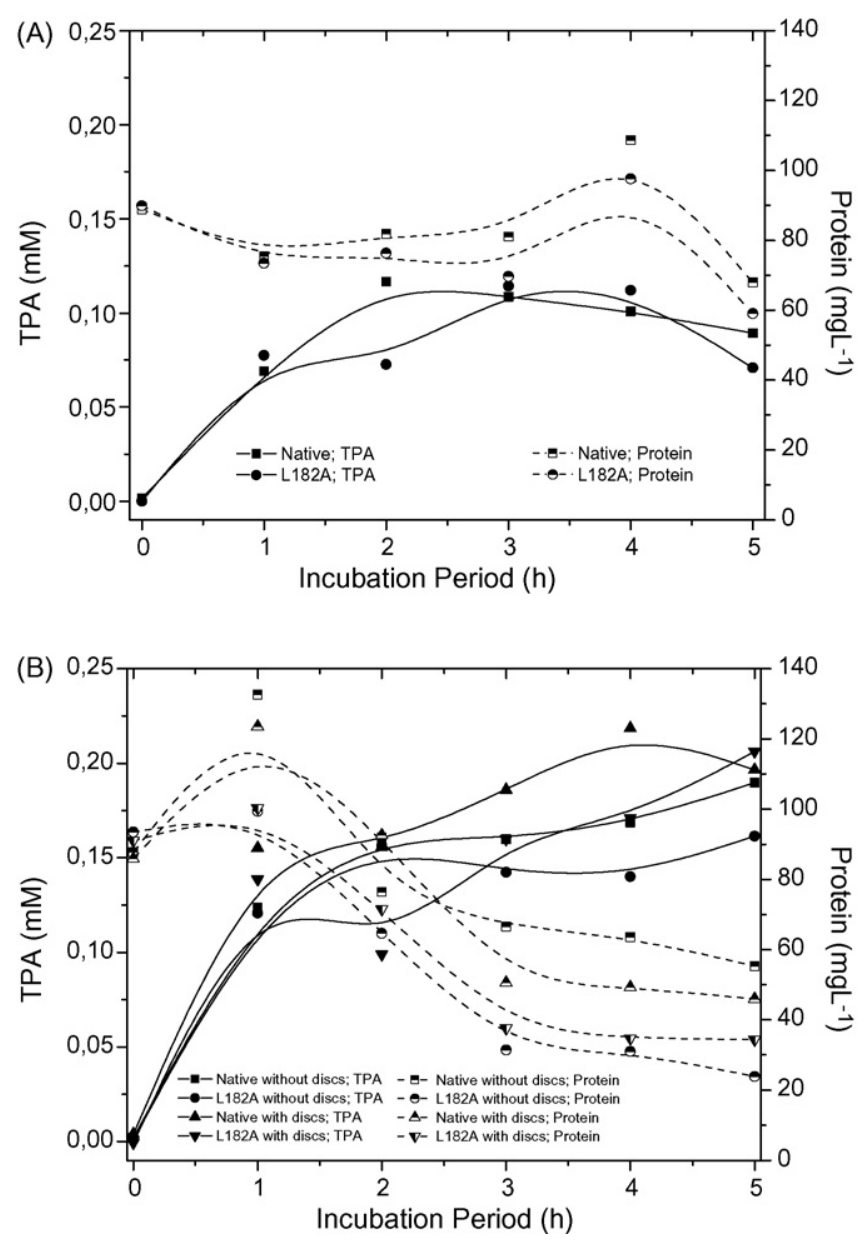

Fig. 1. Terephthalic acid concentration and remaining protein concentration in the incubation liquor in a shaker bath (A) and a Rotawash machine with and without stainless steel discs (B) for different incubation periods. Initial cutinase dosed is $100 \mathrm{mg}_{\text {prot }} \mathrm{L}^{-1}$.

The highest amount of TPA formed in solution was obtained under higher levels of mechanical agitation used for both enzymes (native and genetically modified cutinase). In case of applying orbital agitation (shaker bath), the concentration of TPA in solution was nearly two-fold lower.

The higher amount of TPA (hydrolysis reaction product) in the enzymatic treatment solutions with high levels of mechanical agitation (Rotawash) can be due to the mechanical agitation action on the PET fibres, raising the broken ends and creating microfibrils that result in more sites in the fibre for cutinase attack $[15,16]$. However, no TPA was detected in solution without enzyme with low or high levels of mechanical agitation.

After $5 \mathrm{~h}$ of incubation, almost the same amount of TPA was formed in solution at a lower activity of the genetically modified when compared to the native one $\left(22.1 \mathrm{U} \mathrm{L}^{-1}\right.$ of native cutinase and $12.5 \mathrm{U} \mathrm{L}^{-1}$ of L182A). Since the same amount of protein was used at the beginning of the incubation for both enzymes, this result indicate that using less units of activity on pNPP with the genetically modified cutinase, the same activity on PET is obtained. The activity on a soluble substrate is different on an insoluble one as PET fibre, since with only $12.5 \mathrm{U} \mathrm{L}^{-1}$ of L182A the same amount of TPA was detected in the enzymatic treatment liquor as for the $22.1 \mathrm{UL}^{-1}$ used for the native enzyme.

This behaviour was obtained for both types of mechanical agitation $(\approx 0.10 \mathrm{mM}$ - native and L182A in shaker bath and $\approx 0.20 \mathrm{mM}$ - native and L182A in Rotawash). A constant value, corresponding to a saturation level, could be expected if longer incubation periods were used. That specific profile was not observed since only short periods were used in this study.

Both enzymes had the highest adsorption when the strongest mechanical agitation was used (Rotawash). At the end of the incubation period, the adsorption levels were $37 \%$ for Rotawash without discs, $47 \%$ for Rotawash with discs and only $24 \%$ for the shaker bath, all for the native cutinase. For the genetically modified cutinase L182A, the difference between the several mechanical agitation levels was even bigger, with $75 \%$ for Rotawash without discs, $62 \%$ for Rotawash with discs and only $34 \%$ for the shaker bath. When the strongest mechanical agitation was used, the maximum adsorption values were obtained with the genetically modified cutinase L182A.

The effect of the presence of the stainless steel discs is not so pronounced in the genetically modified cutinase (L182A) compared to the native enzyme. This result was already expected since the mutant L182A was specially designed for better accommodation of the PET fibre as a substrate. Therefore, the native enzyme seems to be more influenced by the action of agitation. The change of leucine 182 by an alanine resulted in an enlargement of the area around the active site and consequently, better accommodation of the substrate [1]. Due to this, the effect of

Table 1

Values of percentage of protein adsorbed after 1,2,3,4 and $5 \mathrm{~h}$ of incubation with native and genetically modified cutinases with different modes of mechanical agitation (Shaker bath with $80 \mathrm{rpm}$ and Rotawash machine with $40 \mathrm{rpm}$ ) at $35^{\circ} \mathrm{C}$

\begin{tabular}{|c|c|c|c|c|c|c|}
\hline \multirow{3}{*}{$\begin{array}{l}\text { Incubation } \\
\text { time }(\mathrm{h})\end{array}$} & \multicolumn{6}{|l|}{ Protein adsorbed (\%) } \\
\hline & \multicolumn{3}{|l|}{ Native cutinase } & \multicolumn{3}{|c|}{ Genetically modified cutinase L182A } \\
\hline & Shaker bath (80 rpm) & $\begin{array}{l}\text { Rotawash without } \\
\text { discs ( } 40 \mathrm{rpm})\end{array}$ & $\begin{array}{l}\text { Rotawash with } \\
\text { discs (40 rpm) }\end{array}$ & $\begin{array}{l}\text { Shaker bath } \\
(80 \mathrm{rpm})\end{array}$ & $\begin{array}{l}\text { Rotawash without } \\
\text { discs }(40 \mathrm{rpm})\end{array}$ & $\begin{array}{l}\text { Rotawash with } \\
\text { discs (40 rpm) }\end{array}$ \\
\hline 1 & 15 & - & - & 18 & - & - \\
\hline 2 & 8 & 13 & - & 15 & 31 & 21 \\
\hline 3 & 9 & 24 & 41 & 23 & 66 & 59 \\
\hline 4 & - & 28 & 43 & - & 67 & 62 \\
\hline 5 & 24 & 37 & 47 & 34 & 75 & 62 \\
\hline
\end{tabular}


the stainless steel discs is not so pronounced for the genetically modified cutinase (L182A) as for the native. The surface displayed hydrophobic amino acids influence the adsorption behaviour of proteins. In this case, the change was one amino acid (leucine) into another (alanine), which is more hydrophobic. As the primary goal of this change was enlargement of the active site, via change of one amino acid, changes to the adsorption behaviour were not expected, however, some influence to this was noted as detailed previously.

The vertical agitation using the Rotawash machine was by itself much more effective for hydrolysis (TPA formation) and protein adsorption than the lower agitation level (orbital agitation) for both enzymes (native and genetically modified cutinases). This fact is due to the beating effects of the type of Rotawash agitation (vertical). Also, the abrasion provoked
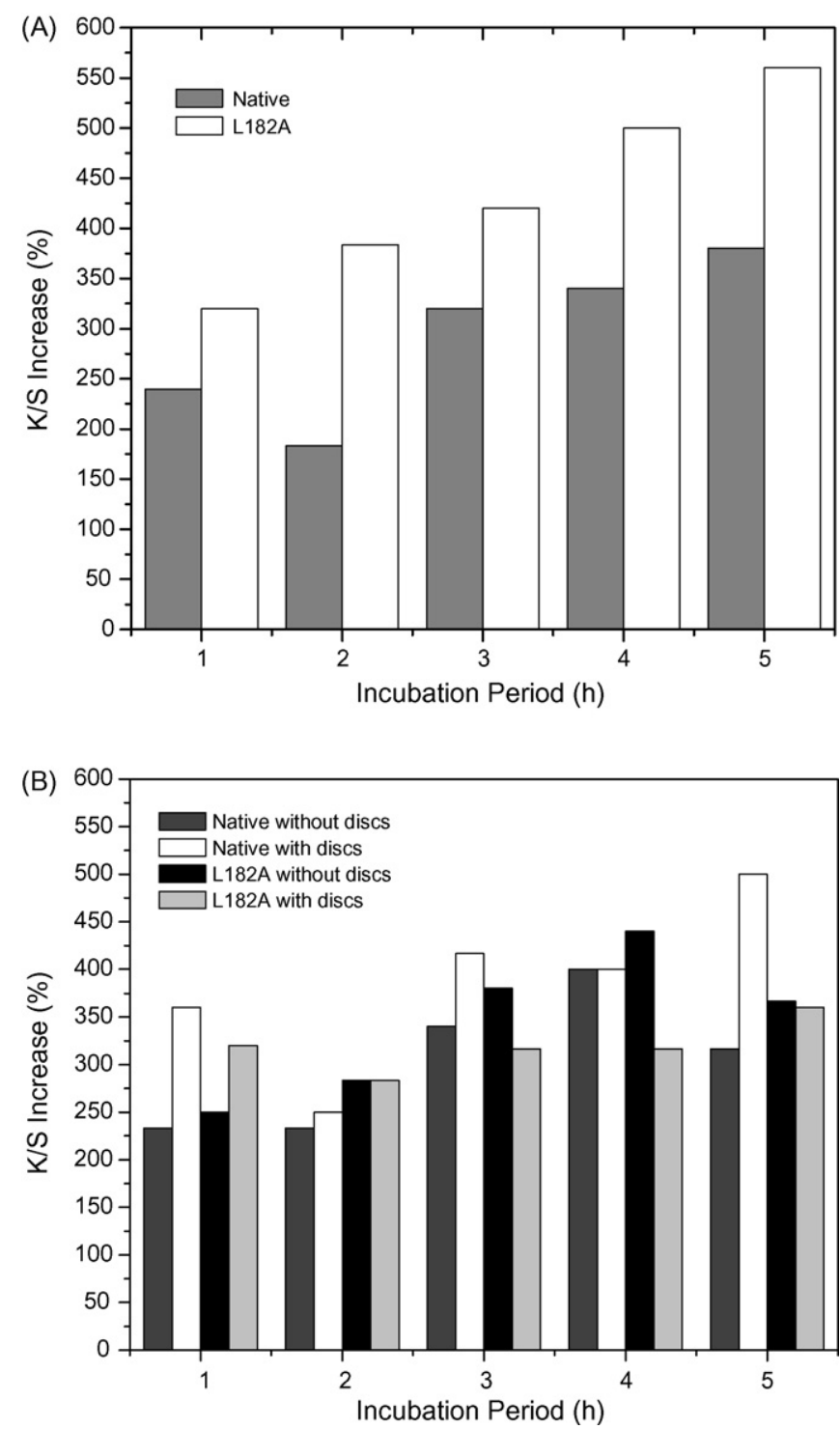

Fig. 2. $K / S$ values at $600 \mathrm{~nm}$, in percentage relative to stained control samples, for polyester after staining with reactive black $5(10 \%$, v/v). Fabric samples were treated with $100.0 \mathrm{mg}_{\text {prot }} \mathrm{L}^{-1}$ of cutinase (native and genetically modified L182A) for indicated incubation periods, both in a shaker bath (A) and Rotawash (B). by fibre-metal friction of the stainless steel discs increases the effect of this type of agitation [20].

The enzymatic hydrolysis at the surface of the polyester fabric generates not only terephthalic acid (product of the hydrolysis) but also hydroxyl end groups. The hydroxyl end groups can be detected by reaction with cotton reactive dyes and their amount by quantification as $K / S$. After the enzymatic treatment, control samples (incubated without enzyme in buffer solution) and enzymatically treated samples were dyed with reactive dye (Reactive Black 5) and the $K / S$ increase in percentage relative to control is shown in Fig. 2(A and B).

At lower level of agitation a systematic increase of hydroxyl end groups is verified for both enzymes. On the Rotawash machine, the increase of hydroxyl end groups is inconsistent as whilst the strong mechanical agitation enhances hydrolysis, it also results in the release of soluble and/or insoluble hydroxyl end groups to the bath. No visible debris is formed in the pots during the treatments with the Rotawash and it can be assumed that only soluble oligomers and/or monomers are released to the solution. The higher level of agitation results in greater amount of hydrolysis in terms of TPA in solution. Since PET is produced from polyethylene glycol and TPA, the hydrolysis of ester bonds will generate equal amounts of hydroxyl $(\mathrm{OH})$ and carbonyl $(\mathrm{COOH})$ groups. However, this hydrolysis also generates oligomeric products, either in solution or on the fabric surface. With the highest level of mechanical agitation, these products are removed from the fabric surface and released to the enzymatic treatment solution. Therefore, the highest $K / S$ increase was obtained for the sample treated with the genetically modified cutinase (L182A) at the lowest mechanical agitation (shaker bath).

Additionally, FT-IR spectra were obtained for both control and enzymatically treated samples. However, no significant differences were detected with this method.

\section{Conclusions}

Mechanical agitation greatly enhances the hydrolysis process of PET fibres, measured as TPA formation. Turnover yields are very low for both cutinases, as no significant changes are verified in fabric appearance. The major advantage of enzyme treatment seems to be the formation of hydroxyl end groups at the surface of the fibres. These groups can be used to attach surface finishing agents to the fibre. The results of our work indicate that surface functionalisation is better done at low levels of mechanical agitation. Our results have important application to the design of an industrial process to functionalize PET with enzymes, where padding processes can be chosen.

\section{Acknowledgements}

This work was supported by the Biosyntex Project, no. G5RD-CT-2000-30110, from European Community under the "Competitive and Sustainable Growth" Program, and by the PhD grant SFRH/BD/22149/2005, from Fundação para a Ciência e a Tecnologia (Portugal). 


\section{References}

[1] O’Neill A, Silva C, Araújo R, Micaelo N, Guebitz G, Soares C, et al. Tailoring cutinase activity towards polyethylene terephthalate and polyamide 6.6 fibers. J Biotechnol 2007;128:849-57.

[2] Carvalho CML, Aires-Barros MR, Cabral JMS. Cutinase: from molecular level to bioprocess development. Biotechnol Bioeng 1999;66(1): $17-34$.

[3] Silva C, Carneiro F, O'Neill A, Fonseca LP, Cabral JMS, Guebitz G, et al Cutinase - a new tool for biomodification of synthetic fibres. J Polym Sci Part A: Polym Chem 2005;43:2448-50.

[4] Cavaco-Paulo A, Almeida L. Effects of agitation and endoglucanase pretreatment on the hydrolysis of cotton fabrics by a total cellulase. Textile Res J 1996;66:287-94.

[5] Azevedo H, Bishop D, Cavaco-Paulo A. Effects of agitation level on the adsorption, desorption and activities on cotton fabrics of full length and core domains of EGV (Humicola insolens) and CenA (Cellulomonas fimi). Enzyme Microbial Technol 2000;27:325-9.

[6] Palonen H, Tjerneld F, Zacchi G, Tenkanen M. Adsorption of Trichoderma reesei $\mathrm{CBH}$ I and EG II and their catalytic domains on steam pretreated softwood and isolated lignin. J Biotechnol 2004;107:65-72.

[7] Azevedo H, Ramos L, Cavaco-Paulo A. Desorption of cellulases from cotton powder. Biotechnol Lett 2001;23:1445-8.

[8] Cavaco-Paulo A, Almeida L, Bishop D. Hydrolysis of cotton cellulose by engineered cellulases from Trichoderma reesei. Textile Res J 1998;68(4):273-80.

[9] Stuart M. Macromolecular adsorption: a brief introduction. In: Malmsten M, editor. Surfactant science series, vol. 110-biopolymers at interfaces. 2nd ed. New York: Marcel Dekker Inc.; 2003. p. 1.
[10] Norde W. Driving forces for protein adsorption at solid surfaces. In: Malmsten M, editor. Surfactant science series, vol. 110-biopolymers at interfaces. 2nd ed. New York: Marcel Dekker Inc.; 2003. p. 21, 30, 39-40.

[11] Kim J, Yoon J. Protein adsorption on polymer particles: some applications. In: Somasundarann P, editor. Encyclopedia of surface and colloid science, update supplement. New York: Marcel Dekker Inc.; 2004. p. 1-5.

[12] Nicolau Jr D, Nicolau D. Towards a theory of protein adsorption mechanism of cellulase action in textile process. Carbohydr Polym 2004;37:273-7.

[13] Maldonado-Valderrama J, Fainerman V, Aksenenko E, Gálvez-Ruiz M, Cabrerizo-Vílchez M, Miller R. Dynamics of protein adsorption at the oilwater interface: comparison with a theoretical model. Colloids Surf A: Physicochem Eng Aspects 2005;261:85-92.

[14] Cortez J, Ellis J, Bishop D. Cellulase finishing of woven, cotton fabrics in Jet and winch machines. J Biotechnol 2001;89:239-45.

[15] Cavaco-Paulo A. Mechanism of cellulase action in textile process. Carbohydr Polym 1998;37:273-7.

[16] Morgado J, Cavaco-Paulo A. Enzymatic treatment of Lyocell—clarification of depilling mechanisms. Textile Res J 2000;70(8):696-9.

[17] Shirai K, Jackson RL. Lipoprotein lipase-catalyzed hydrolysis of $p$ nitrophenyl butyrate. Interfacial activation by phospholipid vesicles. J Biol Chem 1982;257:1253-8.

[18] O'Neill A, Cavaco-Paulo A. Monitoring biotransformations in polyesters. Biocatal Biotransform 2004;22(5/6):353-6.

[19] Bradford M. A rapid and sensitive method for the quantification of microgram quantities of protein utilizing the principles of protein-dye binding. Anal Biochem 1976;72:248-54.

[20] Silva C, Araújo R, Casal M, Gübitz G, Cavaco-Paulo A. Influence of mechanical agitation on cutinases and protease activity towards polyamide substrates. Enzyme Microbial Technol 2007;40:1678-85. 